\title{
An Assessment of Factors Influencing Job Satisfaction of Healthcare Professionals in Ogun State Hospitals, Nigeria
}

\author{
Ahmed Babatunde Jimoh ${ }^{1 *}$, Oluwafemi Tinuola ${ }^{2}$ \\ ${ }^{1}$ State Hospital, Ilaro, Ogun State Hospitals Management Board, Nigeria \\ ${ }^{2}$ School of Public Health Programs, Texila American University, Guyana, South America
}

\begin{abstract}
In the healthcare sector, the job satisfaction of professionals and/or healthcare workers plays a profound role in their performance and is further reflected in the health and satisfaction of the patient. In recent times, the healthcare workers in Nigeria were not seen to be gratified with the organizational policies. The various industrial unions of the health care professionals have engaged in several industrial strike actions over the years in an attempt to demand for better remuneration, improved working conditions, increased staff strength, reduction of work overload, and the likes. This situation among the healthcare professional has become worrisome in Ogun State. This study assessed factors influencing job satisfaction of healthcare professionals in Ogun State Hospitals, Nigeria. The study was conducted with a sample of 729 healthcare professionals from the five zonal offices comprising ThirtyNine (39) Health facilities across the study area. Data and/or items that assessed job satisfaction with management, supervision, nature of work/profession, work environment, salary, benefits, and promotion were subjected to exploratory factor analysis in order to group the major constraints variables. The results showed two orthogonal factors in management, two factors in supervision, five factors in nature of work/profession, three factors in a work environment, and three factors in rewards/compensation, which were derived with total explanations of $50.54 \%, 61.30 \%, 58.32 \%$, $58.82 \%$, and $68.68 \%$ respectively, of the Variance. Only variables with constraints loadings of 0.60 and above were used in naming the factors. The results further revealed that rewards, opportunities for career development, working conditions, and promotional schemes of the organizations have high associations with job satisfaction, whereas work environment was found to have low significance towards job satisfaction. This study concludes that the Ogun State Hospitals Management Board needs to improve the work environment; attractive rewards/compensation, opportunities for career development, and promotions.
\end{abstract}

Keywords: Factors, Healthcare Professionals, Job satisfaction, Nigeria, Ogun State Hospitals.

\section{Introduction}

Globally, health policies are necessary to satisfy with efficiency the requirements of quality management in the health sector [1]. By 2030, optimal health care cannot be delivered as nations commit to achieve universal health coverage by simply ensuring the coexistence of infrastructure, medical supplies, and health care providers. Improving the quality of health services is a continuing challenge to managers in the health system [2]. In the healthcare sector, the job satisfaction of professionals and/or healthcare workers plays a profound role in their performance and is further reflected in the health and satisfaction of the patients [3,4]. One study state that positive or favourable attitudes towards the job indicate job satisfaction while negative or unfavourable attitudes towards their job indicate job dissatisfaction [5]. For the optimum performance and quality of service delivery, the workforce needs to be regularly motivated 
through either financial or non-financial incentives to get satisfied to their work $[6,7,8$, $9,10]$.

There are factors influencing job satisfaction among healthcare workers/professions all over the world. In Sub-Sahara African, increased turnovers, inadequacy, retention, and the perpetual weakening quality of services delivery continue to frustrate healthcare workers, making it difficult for the realization of the health indicators in most African countries [11, 12]. Nigeria has been facing a certain shortage of professionals in the healthcare sector. Workforce dissatisfaction has a negative impact on the performance of the facilities [13].

In recent times, the healthcare workers in Nigeria are not gratified with the organizational policies. For example, thirty-nine (39) Hospitals under the management of the Ogun State Hospitals Management board currently provide secondary care across the State. The various industrial unions of the health care professionals have engaged in several industrial strike actions over the years in an attempt to demand for better remuneration, improved working conditions, increased staff strength, reduction of work overload, and the likes.

The migration of healthcare professionals from the Ogun State HMB to Tertiary Hospitals owned by the Federal Government within the State has become worrisome. Surveys have shown that the numbers of healthcare professionals employed by the State's HMB would decline by half within a year of their employment due to seeking greener pastures elsewhere. This has led to progressive staff attrition with resulting work overload and stress for the healthcare professionals left in the service that cannot efficiently and effectively deliver quality healthcare service to the populace.

In addition, patients visiting the hospital on delay in accessing services have made several complaints, as they have to wait for long hours, cope with the attitude of overstretched healthcare professionals, lack of doctors on sit and many more, which could be attributed to acute shortage of human resources.

Studies also showed that when health service providers are dissatisfied, despite the efforts and energy they put into their work, they tend to reveal this factor when interacting with patients and other staff members. A dissatisfied health service provider poses a potential risk for healthcare-related accidents, and this may negatively influence the mental health and quality of care delivery of such workers [14]. Few studies have recently been conducted on job satisfaction in Nigeria, but little or no studies have been conducted on the factors influencing job satisfaction of healthcare workers and/or professionals in Ogun State Hospitals Management Board. This study assessed the factors influencing job satisfaction among the healthcare professionals in Ogun State Hospitals, Nigeria.

\section{Materials and Methods}

The study area was confined to Ogun State Hospitals Management Board, Ogun State, Nigeria. Ogun State is one of the fastest developing states in the country. It lies in the southwestern part of the country between latitudes $6.2^{\circ} \mathrm{N}$ and $7.8^{\circ} \mathrm{N}$ of the equator and longitudes $3.0^{\circ} \mathrm{E}$ and $5.0^{\circ}$ East of the Greenwich Meridian (Figure. 1). Ogun State occupies an area of $16,980.55 \mathrm{~km}^{2}$ and a population of $3,751,140$, with a density of $220 / \mathrm{km}^{2}$ [15]. The geographical location of the State makes it accessible to the economically developed regions in Nigeria. Ogun State is made up of 20 Local Government Areas (Figure. 1).

The Ogun State Hospitals Management Board's headquarters is situated at Block A, State Secretariat Complex, Oke-Mosan, Abeokuta. The military Government with the objective to provide effective, qualitative, and quantitative healthcare services to the people of Ogun State, established the agency in 1978. The Ogun HMB has five (5) zonal offices (Abeokuta, Ijebu Ode, Ota, Sagamu, and Ilaro Health Zones). The Ogun HMB has under it Five (5) 
State Hospitals, Five (5) Dental Centres, Four (4) Community Mental Health Centres, and Twenty-five (25) General Hospitals with a total of Thirty-Nine (39) Health facilities [16].

The method employed in this study involved a cross-sectional descriptive study design, and it was conducted among the healthcare professionals in Ogun State Hospitals Management Board. A multi-stage sampling technique was adopted to obtain relevant information from the healthcare professionals in the study area. Data were collected mainly with a self-administered structured and unstructured questionnaire in the five (5) zonal offices which comprising all the twenty (20) Local
Government Areas in Ogun State, Nigeria. When the actual number of healthcare workers was insufficient, all the available healthcare workers (729) were given the questionnaires to fill, which were retrieved, coded in excel Microsoft Package. Descriptive and inferential statistics were employed, and exploratory factor was used in grouping the job satisfaction variables into major factors. However, only variables with loadings of 0.60 and above were used in naming the factors. Analysis was done using Statistical Package for Social Sciences (SPSS) version 23, while the results were presented in frequencies tables, graphs, and pie charts.

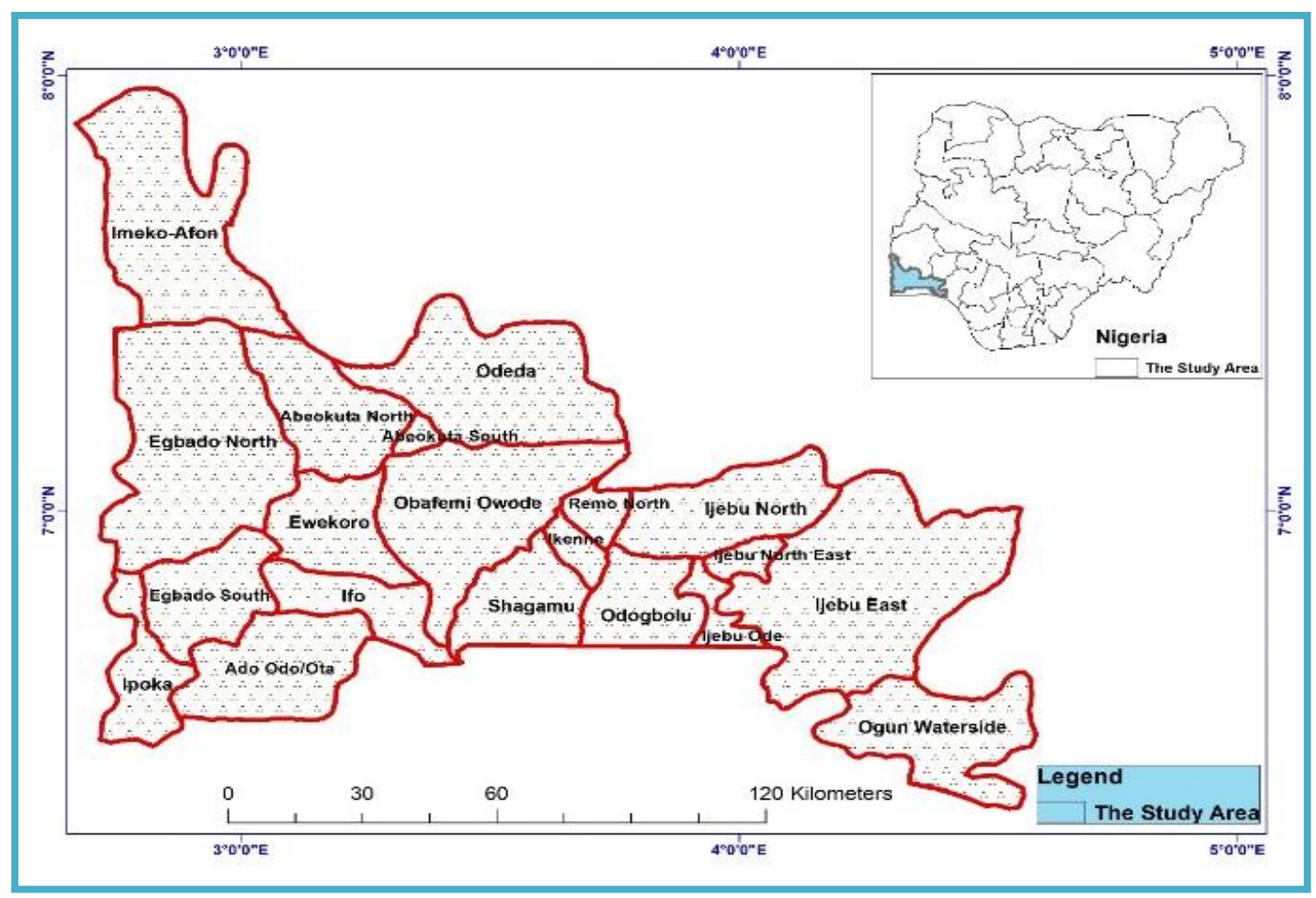

Figure 1. Ogun State, the Study Area

\section{Results}

\section{Demographic Characteristics of the Respondents in the Study Area}

Table 1-2 and Figure. 2-3 present the demographic characteristics of the respondents in the study area. In table 4.1, most participants were female $(73.5 \%)$; and $83.0 \%$ of them were married. The majority of the respondents, 261 (35.8\%) were between the ages 31 and 40, while
$249(34.2 \%)$ were between 41 and 50 years. Of the total respondents, $606(83.1 \%)$, were single (unmarried) and the least percentage of the respondents constituted those who have divorced with the percentage of 1.2 (Figure. 2). The number of respondents with university education constituted larger percentage with $56.5 \%$; the least number of respondents which represents only $16.5 \%$, had postgraduate 
education, while non-graduate respondents constituted a total of 197 (27.0\%).

The Nurses were the majority of the healthcare workers, constituting a total of 388 (53.2\%) of the respondent, followed by the Doctors $110(15.1 \%)$ and other professionals in Ogun State Hospitals Management Board (Table 1). A very small number of respondents which represents $11.2 \%$, have spent more than 20 years, while $36.1 \%$ and $30.0 \%$ of the respondents indicated to have spent between 10-
20 and less than 5 years in the study area (Figure. 3). Table 2 shows the distribution of the healthcare workers across the 39 health facilities under the management of the Ogun State Hospital Management Board (the study area). The results of this study showed that the healthcare workers were not evenly distributed, while Ijaiye had the highest number of healthcare workers with a total of 167 , which represent $22.9 \%$.

Table 1. Demographic Characteristics of the Respondents

\begin{tabular}{|c|c|c|c|}
\hline \multicolumn{2}{|c|}{ Demographic Characteristics } & \multirow{2}{*}{$\begin{array}{l}\text { Frequency } \mathbf{N}=\mathbf{7 2 9} \\
193\end{array}$} & \multirow{2}{*}{$\begin{array}{l}\text { Percent } \\
26.5\end{array}$} \\
\hline Gender & Male & & \\
\hline & Female & 536 & 73.5 \\
\hline \multirow[t]{4}{*}{ Age Bracket } & Less than 30 & 112 & 15.4 \\
\hline & $31-40$ & 261 & 35.8 \\
\hline & $41-50$ & 249 & 34.2 \\
\hline & 50 and above & 107 & 14.7 \\
\hline \multirow[t]{4}{*}{ Marital Status } & Married & 606 & 83.1 \\
\hline & Unmarried & 99 & 13.6 \\
\hline & Divorced & 9 & 1.2 \\
\hline & Widowed & 15 & 2.1 \\
\hline \multirow[t]{3}{*}{ Education Level } & Diploma & 197 & 27.0 \\
\hline & Graduate & 412 & 56.5 \\
\hline & Postgraduate & 120 & 16.5 \\
\hline \multirow[t]{15}{*}{ Profession } & Doctor & 110 & 15.1 \\
\hline & Dentist & 20 & 2.7 \\
\hline & Nurse & 388 & 53.2 \\
\hline & Pharmacist & 37 & 5.1 \\
\hline & Medlab Scientist & 35 & 4.8 \\
\hline & Physiotherapist & 16 & 2.2 \\
\hline & Dietician/Nutritionist & 13 & 1.8 \\
\hline & Lab Technician & 44 & 6.0 \\
\hline & Pharm. Technician & 38 & 5.2 \\
\hline & Dental Assistant/Therapist & 14 & 1.9 \\
\hline & Radiographer & 4 & 0.5 \\
\hline & Dental Technologist & 5 & 0.7 \\
\hline & Optometrist & 2 & 0.3 \\
\hline & X-ray Technician & 3 & 0.4 \\
\hline & Total & 729 & 100.0 \\
\hline
\end{tabular}




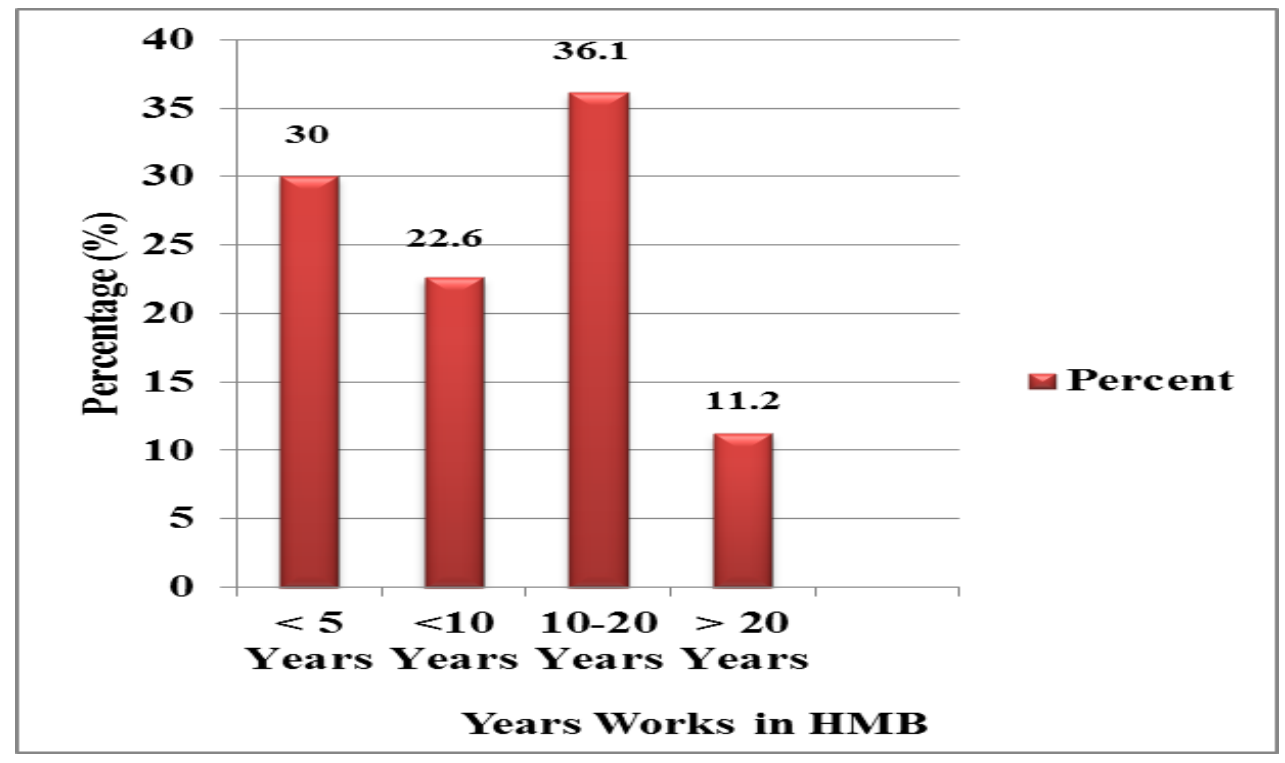

Figure 2. Distribution of the Years spent in service of the HMB

Table 2. Distribution of Healthcare Workers across the Health Facilities

\begin{tabular}{|l|l|l|}
\hline Name of Facility & Frequency & Percent (\%) \\
\hline Community Hospital Ilisan & 7 & 1.0 \\
\hline Community Hospital Isaga Orile & 4 & 0.5 \\
\hline Community Mental Health Centre Ijebu-Ode & 3 & 0.4 \\
\hline Community Mental Health Centre Ilaro & 3 & 0.4 \\
\hline Community Psychiatric Centre Ota & 4 & 0.5 \\
\hline Community Psychiatry Abeokuta & 9 & 1.2 \\
\hline Dental Centre Abeokuta & 17 & 2.3 \\
\hline Dental Centre Ayetoro & 2 & 0.3 \\
\hline Dental Centre Ijebu-ode & 9 & 1.2 \\
\hline Dental Centre OTA & 5 & 0.7 \\
\hline Dental Centre Sagamu & 7 & 1.0 \\
\hline General Hospital Ala-idowa & 10 & 1.4 \\
\hline General Hospital Atan & 7 & 1.0 \\
\hline General Hospital Ayetoro & 18 & 2.5 \\
\hline General Hospital Iberekodo & 9 & 1.2 \\
\hline General Hospital Ibiade & 8 & 1.1 \\
\hline General Hospital Idiroko & 15 & 2.1 \\
\hline General Hospital IFO & 26 & 3.6 \\
\hline General Hospital Ijebu-ife & 11 & 1.5 \\
\hline General Hospital Ijebu-igbo & 15 & 2.1 \\
\hline General Hospital Ikenne & 10 & 1.4 \\
\hline General Hospital Imeko & 10 & 1.4 \\
\hline General Hospital Iperu & 12 & 1.6 \\
\hline General Hospital Ipokia & 5 & 0.7 \\
\hline General Hospital Itori & 10 & 1.4 \\
\hline General Hospital Ode-Lemo & 5 & 0.7 \\
\hline General Hospital Odeda & 13 & 1.8 \\
\hline
\end{tabular}




\begin{tabular}{|l|l|l|}
\hline General Hospital Odogbolu & 10 & 1.4 \\
\hline General Hospital Ogbere & 5 & 0.7 \\
\hline General Hospital Omu-ijebu & 9 & 1.2 \\
\hline General Hospital owode-egba & 16 & 2.2 \\
\hline Hansen Clinic Iberekodo & 8 & 1.1 \\
\hline Oba Ademola Maternity Abeokuta & 24 & 3.3 \\
\hline Olikoye Ransom Kuti Memorial Hospital, Abeokuta & 34 & 4.7 \\
\hline State Hospital Ijaiye & 167 & 22.9 \\
\hline State Hospital Ijebu-Ode & 68 & 9.3 \\
\hline State Hospital Ilaro & 38 & 5.2 \\
\hline State Hospital Isara & 37 & 5.1 \\
\hline State Hospital Ota & 59 & 8.1 \\
\hline Total & $\mathbf{7 2 9}$ & $\mathbf{1 0 0}$ \\
\hline
\end{tabular}

\section{Factors Responsible for Job Satisfaction or Job Dissatisfaction of Healthcare Professionals in the Study Area}

The data and/or items that evaluate job satisfaction with management, supervision, nature of work/profession, work environment, salary, benefits, and promotion were subjected to exploratory factor analysis in order to group the constraints variables. The results of the rotated component matrix showing the extracted factors based on the responses of respondents are shown in Table 3-7 below. The results showed two orthogonal factors in management, two factors in supervision, five factors in nature of work/profession, three factors in work environment, and three factors in rewards, which were derived with total explanations of $50.54 \%$, $61.30 \%, 58.32 \%, 58.82 \%$, and $68.68 \%$ respectively, of the Variance. Only variables with constraints loadings of 0.60 and above were used in naming the constraints. The Eigen values, percentage of Variance, and cumulative percentage of the Variance explained are also presented in Table 3-7. In the management aspect of job satisfaction in Ogun State HMB (Table 3), Factor I is tagged "staff development factor" while Factor II is tagged "leadership policy factor". These two factors have an impact on job satisfaction and qualities of healthcare delivery in Ogun State HMB. The eigenvalue of Factor I is 4.95 with $41.28 \%$ of the Variance.
Factor I has very high significant loading on the variable 'The HMB provides for a career opportunity and growth of employees' (0.73) and "The HMB provides for additional training and education support" (0.72), and moderately high loading on the variables 'HMB provide for orientation and training of new employees' (0.69). Factor II has an Eigen value of 1.11 and contributed $9.26 \%$ to the Variance in the management of job satisfaction and quality of healthcare workers in Ogun State HMB. Factor II has the highest loading on 'I am satisfied with the leadership and management style of the HMB', 'The HMB value her employees', and 'HMB's many rules and procedures make doing a good job difficult' with loading points 0.72 , 0.62 and -0.62 respectively.

The two factors extracted from the supervision of job satisfaction and quality of healthcare delivery in Ogun State HMB was designated as supervisory and subordinates (Table 4). The factor I called supervisory is highly loaded in almost all the variables except "My supervisor shows little interest in the feelings of subordinates' and 'My supervisor holds me and other workers accountable for performance'. Factor II is highly loaded on the one constraint variable, namely 'My supervisor shows little interest in the feelings of subordinates' (0.85) and with an Eigen value of 1.12 and contributed $9.34 \%$ to the Variance in 
the supervision of job satisfaction and quality of healthcare workers in the study area.

Regarding the nature of work/profession, five factors were derived with total explanation of $58.32 \%$ of the Variance (Table 5). The extracted five factors were named 'job qualities, resources, job pressure, reward and training'. The factor I, which is named 'job qualities', contributes $28.13 \%$ explanation, and this factor is highly loaded on only two variables: 'I have opportunity to improve my professional skill and knowledge at work' (0.75), 'I am able to provide the best services at my workplace' $(0.70)$ and moderately loaded on six variables. Factor II has very high significant loading on the variable 'My department provides all equipment, supplies, and resources necessary to work with' (0.68) and "I have the autonomy to make decisions in the execution of my work according to the best clinical judgment" (0.72). Factor II has an Eigen value of 2.12 and contributed $10.82 \%$ to the Variance in the profession of job satisfaction and quality of healthcare workers in the study area. Factor III has an eigenvalue of 1.53 with $7.66 \%$ of Variance. The variables are related to job pressure. It has very high significant loadings on the variables 'The job adds significant pressure and anxiety to my life' (0.75) and 'the job demand is too much (physically, emotionally and mentally)' (0.76). Factor IV of the nature of work is related to rewards. It is highly loaded on two variables; 'I would consider leaving my better pay' (0.78) and 'I would consider leaving my job for greater opportunity for advancement' (0.69), with an Eigen value of 1.25 and contributed $6.26 \%$ to the Variance. The variables 'There are services we need to offer that we currently do not' (0.69) and 'I believe I need extra training to perform optimally' (0.68) are significantly loaded with Eigen value of 1.09.

In addition, three factors derived from the work environment as related to job satisfaction of healthcare workers in Ogun State HMB were facility, relationship, and employees' attitudes (Table 6). These factors have 35.02, 16.41, and 7.38 total \% of Variance. All these factors have an effect on healthcare worker's job satisfaction in the study area with total explanations of $58.82 \%$ contribution.

Finally, promotion, salary, and benefits were three major factors derived from the rewards as it has an impact on job satisfaction of healthcare workers in Ogun State HMB (Table 7). It has a total Cumulative \% of Variance Explained of 68.68 (4.13). The factor I named 'promotion 'contributes $37.04 \%$ explanation and this factor is positively and highly loaded on 'I am satisfied with my chances of promotion', 'I am satisfied with regards to illness benefits, disability benefits and life insurance', 'I am satisfied with my retirement plan benefits', and 'I am satisfied with my salary'. Factor II has an eigenvalue of 1.68 with $18.69 \%$ of Variance. The variables are related to job salary. It has very high significant loadings on the variables 'The salary received is good as most other organizations offers' $(0.86)$ and 'I get decent salary for the job I perform' (0.81). The third factor is benefits. It has high loadings on three variables such as 'I don't feel my efforts are rewarded the way they should, 'there are benefits we don't have which we should', and 'The influence of trade union contract on the existing salary system' with loading values of $0.79, \quad 0.76$ and 0.67 respectively.

Table 3. Managerial Factors for Job Satisfaction in HMB

\begin{tabular}{|l|l|l|}
\hline Items Description & Factor 1 & Factor 2 \\
\hline $\begin{array}{l}\text { Policies of HMB to create a conducive work } \\
\text { environment }\end{array}$ & 0.545 & 0.391 \\
\hline $\begin{array}{l}\text { HMB's many rules and procedures make doing } \\
\text { a good job difficult }\end{array}$ & 0.493 & -0.616 \\
\hline The HMB is supportive of her employees & 0.533 & 0.463 \\
\hline
\end{tabular}




\begin{tabular}{|l|l|l|}
\hline $\begin{array}{l}\text { HMB provide for orientation and training of } \\
\text { new employees }\end{array}$ & 0.688 & 0.224 \\
\hline $\begin{array}{l}\text { The HMB provides for career opportunity and } \\
\text { growth of employees }\end{array}$ & 0.725 & 0.286 \\
\hline $\begin{array}{l}\text { The HMB provides for additional training and } \\
\text { education support }\end{array}$ & 0.721 & 0.27 \\
\hline The HMB value her employees & 0.514 & 0.622 \\
\hline The HMB provide steady employment & 0.36 & 0.455 \\
\hline $\begin{array}{l}\text { The HMB provide periodic measurement of } \\
\text { individual efficiency }\end{array}$ & 0.315 & 0.534 \\
\hline I believe my job is secured with the Agency & 0.237 & 0.563 \\
\hline $\begin{array}{l}\text { I am satisfied with the leadership and } \\
\text { management style of the HMB }\end{array}$ & 0.344 & 0.72 \\
\hline $\begin{array}{l}\text { I am satisfied with the employee's transfer } \\
\text { policy }\end{array}$ & 0.33 & 0.53 \\
\hline Factor Description & Staff Development & Leadership Policies \\
\hline Eigenvalues & 4.954 & 1.111 \\
\hline \% Of Variance & 41.285 & 9.258 \\
\hline Cumulative \% of Variance Explained & 41.285 & 50.543 \\
\hline
\end{tabular}

Extraction Method: Principal Component Analysis

Rotation Method: Varimax with Kaiser Normalization

a. Rotation converged in 3 iterations

Table 4. Supervision Factors for Job Satisfaction in HMB

\begin{tabular}{|c|c|c|c|c|c|}
\hline \multirow[t]{2}{*}{ Items Description } & \multicolumn{5}{|c|}{ Factors } \\
\hline & 1 & 2 & 3 & 4 & 5 \\
\hline I have an accurate written job description & 0.68 & 0.078 & 0.054 & -0.246 & 0.096 \\
\hline $\begin{array}{l}\text { I have the opportunity to improve my } \\
\text { professional skill and knowledge at work }\end{array}$ & 0.746 & 0.052 & 0.084 & -0.151 & 0.009 \\
\hline $\begin{array}{l}\text { I am provided with the necessary } \\
\text { training to perform to satisfaction }\end{array}$ & 0.675 & 0.181 & 0.162 & -0.074 & -0.282 \\
\hline $\begin{array}{l}\text { I feel overwhelmed by my } \\
\text { responsibilities at work }\end{array}$ & 0.526 & -0.06 & 0.502 & -0.003 & -0.073 \\
\hline $\begin{array}{l}\text { The job adds significant pressure and } \\
\text { anxiety to my life }\end{array}$ & -0.112 & 0.02 & 0.75 & 0.226 & 0.044 \\
\hline $\begin{array}{l}\text { The job demand is too much (physically, } \\
\text { emotionally and mentally) }\end{array}$ & -0.051 & 0.02 & 0.762 & 0.205 & 0.15 \\
\hline $\begin{array}{l}\text { I am fully able to use my skill in the } \\
\text { present position. }\end{array}$ & 0.614 & 0.241 & 0.032 & 0.039 & -0.112 \\
\hline $\begin{array}{l}\text { I am satisfied at the level of quality } \\
\text { services delivered in my facility }\end{array}$ & 0.525 & 0.576 & 0.087 & -0.053 & -0.133 \\
\hline $\begin{array}{l}\text { My department provides all equipment, } \\
\text { supplies, and resources necessary to } \\
\text { work with. }\end{array}$ & 0.369 & 0.684 & 0.058 & -0.046 & -0.167 \\
\hline
\end{tabular}




\begin{tabular}{|l|l|l|l|l|l|}
\hline $\begin{array}{l}\text { I have autonomy to make decisions in } \\
\text { execution of my work according to the } \\
\text { best clinical judgment. }\end{array}$ & 0.101 & 0.716 & 0.105 & -0.225 & 0.323 \\
\hline $\begin{array}{l}\text { I believe I need extra training to perform } \\
\text { optimally }\end{array}$ & 0.173 & -0.046 & 0.018 & 0.039 & 0.683 \\
\hline I feel positive and happy doing my work & 0.692 & 0.091 & -0.132 & -0.097 & 0.33 \\
\hline I would consider leaving my better pay & -0.05 & 0.067 & 0.192 & 0.779 & 0.018 \\
\hline $\begin{array}{l}\text { I would consider leaving my job for } \\
\text { greater opportunity for advancement }\end{array}$ & 0.006 & -0.129 & 0.25 & 0.688 & 0.165 \\
\hline $\begin{array}{l}\text { I have energy at the end of workday to } \\
\text { engage in personal interest }\end{array}$ & 0.183 & 0.57 & -0.242 & 0.273 & -0.048 \\
\hline $\begin{array}{l}\text { I have ample opportunities for } \\
\text { advancement in my career. }\end{array}$ & 0.566 & 0.286 & -0.144 & 0.206 & 0.094 \\
\hline $\begin{array}{l}\text { I am able to live a happy home-life with } \\
\text { realization of my aspirations }\end{array}$ & 0.627 & 0.223 & -0.288 & 0.261 & 0.181 \\
\hline $\begin{array}{l}\text { I am able to command respect and } \\
\text { dignity from my job. }\end{array}$ & 0.625 & 0.276 & -0.234 & 0.15 & 0.298 \\
\hline $\begin{array}{l}\text { I am able to provide the best services at } \\
\text { my workplace }\end{array}$ & 0.704 & 0.215 & -0.209 & 0.165 & 0.091 \\
\hline $\begin{array}{l}\text { There are services we need to offer that } \\
\text { we currently do not. }\end{array}$ & -0.057 & 0.029 & 0.129 & 0.107 & 0.688 \\
\hline Factor Description & Job Qualities & Resources & Job Pressure & Reward & Training \\
\hline Eigenvalues & 5.625 & 2.164 & 1.532 & 1.252 & 1.092 \\
\hline \% Of Variance & 28.125 & 10.819 & 7.659 & 6.258 & 5.462 \\
\hline Cumulative \% of Variance Explained & 28.125 & 38.943 & 46.603 & 52.860 & 58.322 \\
\hline
\end{tabular}

Extraction Method: Principal Component Analysis

Rotation Method: Varimax with Kaiser Normalization

a. Rotation converged in 3 iterations

Table 5. Work Environment and Job Satisfaction of Healthcare Workers in HMB

\begin{tabular}{|l|l|l|l|}
\hline \multirow{2}{*}{ Items Description } & \multicolumn{2}{l|}{ Factors } \\
\cline { 2 - 5 } & $\mathbf{1}$ & $\mathbf{2}$ & $\mathbf{3}$ \\
\hline $\begin{array}{l}\text { Availability of aesthetically pleasant physical } \\
\text { environment }\end{array}$ & 0.687 & 0.089 & -0.062 \\
\hline $\begin{array}{l}\text { Provision of water, lighting, ventilation at } \\
\text { workplace }\end{array}$ & 0.735 & 0.096 & -0.137 \\
\hline Availability of security for life and property & 0.796 & 0.026 & 0.004 \\
\hline $\begin{array}{l}\text { Provision of ergonomic comfortability at work } \\
\text { e.g., ergonomic chairs, comfortable call rooms, } \\
\text { etc. }\end{array}$ & 0.762 & 0.011 & 0.123 \\
\hline $\begin{array}{l}\text { Availability of efficient equipment and tools } \\
\text { workplace. }\end{array}$ & 0.797 & 0.105 & 0.061 \\
\hline There is the provision of sanitary facilities. & 0.719 & 0.173 & -0.032 \\
\hline $\begin{array}{l}\text { The building, work area (floor), and layout are } \\
\text { adequate to work efficiently. }\end{array}$ & 0.768 & 0.113 & 0.008 \\
\hline
\end{tabular}




\begin{tabular}{|l|l|l|l|}
\hline $\begin{array}{l}\text { There is an implementation of safety norms in } \\
\text { my workplace }\end{array}$ & 0.762 & 0.204 & -0.058 \\
\hline I have a safe workplace & 0.793 & 0.211 & 0.01 \\
\hline I look forward to going to work daily & 0.534 & 0.381 & -0.158 \\
\hline There is mutual cooperation among co-workers. & 0.291 & 0.563 & -0.308 \\
\hline $\begin{array}{l}\text { I am satisfied with my relationship with my } \\
\text { immediate supervisor }\end{array}$ & 0.078 & 0.817 & -0.075 \\
\hline $\begin{array}{l}\text { I am satisfied with my relationship with my } \\
\text { subordinate }\end{array}$ & -0.045 & 0.833 & -0.008 \\
\hline $\begin{array}{l}\text { I am satisfied with my relationship with other } \\
\text { workers }\end{array}$ & 0.05 & 0.849 & -0.09 \\
\hline $\begin{array}{l}\text { There is a non-threatening way of } \\
\text { communicating the weakness of workers }\end{array}$ & 0.172 & 0.656 & -0.011 \\
\hline $\begin{array}{l}\text { Communications seem good within this } \\
\text { organization }\end{array}$ & 0.214 & 0.7 & -0.133 \\
\hline There is too much bickering and fighting at work & -0.034 & -0.144 & 0.818 \\
\hline $\begin{array}{l}\text { I have the opportunity to give input on decisions } \\
\text { affecting my work }\end{array}$ & 0.155 & 0.571 & 0.076 \\
\hline $\begin{array}{l}\text { I have to work harder at my workplace because } \\
\text { of the incompetence of the people I work with. }\end{array}$ & 0.023 & -0.03 & 0.822 \\
\hline Factor Description & Facility & Relationship & Employee's attitudes \\
\hline Eigenvalues & 6.655 & 3.118 & 1.402 \\
\hline \% Of Variance & 35.027 & 16.412 & 7.381 \\
\hline Cumulative \% of Variance Explained & 51.440 & 58.821 \\
\hline
\end{tabular}

Extraction Method: Principal Component Analysis

Rotation Method: Varimax with Kaiser Normalization

a. Rotation converged in 3 iterations

Table 6. Work Environment and Job Satisfaction of Healthcare Workers in HMB

\begin{tabular}{|l|l|l|l|}
\hline \multirow{2}{*}{ Items Description } & Factors & \multicolumn{2}{l|}{} \\
\cline { 2 - 4 } & $\mathbf{1}$ & $\mathbf{2}$ & $\mathbf{3}$ \\
\hline $\begin{array}{l}\text { Availability of aesthetically pleasant } \\
\text { physical environment }\end{array}$ & 0.687 & 0.089 & -0.062 \\
\hline $\begin{array}{l}\text { Provision of water, lighting, ventilation at } \\
\text { workplace }\end{array}$ & 0.735 & 0.096 & -0.137 \\
\hline $\begin{array}{l}\text { Availability of security for life and } \\
\text { property }\end{array}$ & 0.796 & 0.026 & 0.004 \\
\hline $\begin{array}{l}\text { Provision of ergonomic comfortability at } \\
\text { work e.g., ergonomic chairs, comfortable } \\
\text { call rooms, etc. }\end{array}$ & 0.762 & 0.011 & 0.123 \\
\hline $\begin{array}{l}\text { Availability of efficient equipment and } \\
\text { tools workplace. }\end{array}$ & 0.797 & 0.105 & 0.061 \\
\hline There is a provision of sanitary facilities. & 0.719 & 0.173 & -0.032 \\
\hline $\begin{array}{l}\text { The building, work area (floor), and layout } \\
\text { are adequate to work efficiently. }\end{array}$ & 0.768 & 0.113 & 0.008 \\
\hline
\end{tabular}




\begin{tabular}{|l|l|l|l|}
\hline $\begin{array}{l}\text { There is an implementation of safety } \\
\text { norms in my workplace }\end{array}$ & 0.762 & 0.204 & -0.058 \\
\hline I have a safe workplace & 0.793 & 0.211 & 0.01 \\
\hline I look forward to going to work daily & 0.534 & 0.381 & -0.158 \\
\hline $\begin{array}{l}\text { There is mutual cooperation among co- } \\
\text { workers. }\end{array}$ & 0.291 & 0.563 & -0.308 \\
\hline $\begin{array}{l}\text { I am satisfied with my relationship with } \\
\text { my immediate supervisor }\end{array}$ & 0.078 & 0.817 & -0.075 \\
\hline $\begin{array}{l}\text { I am satisfied with my relationship with } \\
\text { my subordinate }\end{array}$ & -0.045 & 0.833 & -0.008 \\
\hline $\begin{array}{l}\text { I am satisfied with my relationship with } \\
\text { other workers }\end{array}$ & 0.05 & 0.849 & -0.09 \\
\hline $\begin{array}{l}\text { There is a non-threatening way of } \\
\text { communicating the weakness of workers }\end{array}$ & 0.172 & 0.656 & -0.011 \\
\hline $\begin{array}{l}\text { Communications seem good within this } \\
\text { organization }\end{array}$ & 0.214 & 0.7 & -0.133 \\
\hline $\begin{array}{l}\text { There is too much bickering and fighting at } \\
\text { work }\end{array}$ & -0.034 & -0.144 & 0.818 \\
\hline $\begin{array}{l}\text { I have the opportunity to give input on } \\
\text { decisions affecting my work }\end{array}$ & 0.155 & 0.571 & 0.076 \\
\hline $\begin{array}{l}\text { I have to work harder at my workplace } \\
\text { because of the incompetence of the people } \\
\text { I work with. }\end{array}$ & 0.023 & -0.03 & 0.822 \\
\hline Factor Description & Facility & Relationship & Employee's attitudes \\
\hline Eigenvalues & 6.655 & 3.118 & 1.402 \\
\hline$\%$ Of Variance & 35.027 & 16.412 & 5.381 \\
\hline Cumulative \% of Variance Explained & 58.821 \\
\hline
\end{tabular}

Extraction Method: Principal Component Analysis

Rotation Method: Varimax with Kaiser Normalization

a. Rotation converged in 3 iterations

Table 7. Rewards and Job Satisfaction of Healthcare Workers in HMB

\begin{tabular}{|l|l|l|l|}
\hline Items Description & \multicolumn{2}{l}{ Factors } \\
\cline { 2 - 4 } & $\mathbf{1}$ & $\mathbf{2}$ & $\mathbf{3}$ \\
\hline I get a decent salary for the job I perform & 0.312 & 0.813 & 0.059 \\
\hline $\begin{array}{l}\text { The salary received is good as most other } \\
\text { organizations offers }\end{array}$ & 0.093 & 0.858 & 0.125 \\
\hline There are benefits we don't have which we should. & -0.077 & 0.118 & 0.76 \\
\hline $\begin{array}{l}\text { The influence of trade union contract on the } \\
\text { existing salary system. }\end{array}$ & 0.024 & 0.261 & 0.666 \\
\hline $\begin{array}{l}\text { I don't feel my efforts are rewarded the way they } \\
\text { should. }\end{array}$ & 0.129 & -0.179 & 0.793 \\
\hline I am satisfied with my chances of promotion & 0.786 & 0.162 & 0.056 \\
\hline $\begin{array}{l}\text { I am satisfied with regard to illness benefits, } \\
\text { disability benefits, and life insurance. }\end{array}$ & 0.875 & 0.09 & 0 \\
\hline
\end{tabular}




\begin{tabular}{|l|l|l|l|}
\hline I am satisfied with my retirement plan benefits & 0.886 & 0.109 & 0.025 \\
\hline I am satisfied with my salary. & 0.647 & 0.485 & -0.004 \\
\hline Factor Description & Promotion & Salary & Benefits \\
\hline Eigenvalues & 3.334 & 1.682 & 1.166 \\
\hline \% Of Variance & 37.042 & 18.689 & 12.953 \\
\hline Cumulative \% of Variance Explained & 37.042 & 55.731 & 68.684 \\
\hline
\end{tabular}

Extraction Method: Principal Component Analysis

Rotation Method: Varimax with Kaiser Normalization

a. Rotation converged in 3 iterations

\section{Discussion}

Job satisfaction of health care providers plays a great role in providing quality healthcare. From the present study, healthcare professionals were largely sampled with the ratio of male and female of 0.26 to 0.74 . This is because the study was conducted in Ogun State Hospitals, and the population of females was more than males. Most of the healthcare professionals were found to be between the ages of 31 and 50, which corresponds to the report of $[17,18,19]$. Being a Gateway State and one of the foremost educated States in Nigeria, the results of this study showed that the majority of the people in the study are educated, with a very large number of nurses and medical doctors with formal education. Uneven distribution of healthcare works might be attributed to the distribution of health facilities, where the State Hospital Ijaiye had the highest number of healthcare workers.

Findings obtained from this study revealed that there are determinant factors influencing job satisfaction and quality of healthcare delivery in Ogun State Hospitals. The findings of this study clearly showed that many healthcare workers believed that management, nature of work/profession, work environment, and rewards have a great impact on job satisfaction. The findings of this study corroborate with the study of [20]. This study found out two major variables in management, two factors in supervision, five factors in nature of work/profession, three factors in the work environment, and three factors in rewards, which were derived with total explanations of $50.54 \%$, $61.30 \%, 58.32 \%, 58.82 \%$, and $68.68 \%$ respectively, of the Variance. The physical infrastructures being the basic requirement for the effective functioning of an organization, have an important bearing on the job satisfaction of healthcare professionals.

One of the studies revealed that motivators (such as assurance of better working conditions, effective and efficient support system, opportunities for career development, financial incentives, better living conditions, and family support) are required for working in rural communities [21]. These findings are consistent with researches which have documented the need to improve working conditions and salary in a bid to motivate health workers and improve their job satisfaction $[22,23]$. The findings of the working condition and/or work environment were similar to the findings in studies conducted in Ethiopia [11] and Greece [24]. Further, the findings of this study also revealed that healthcare workers have a decent and receive a good salary, satisfied with the chances of promotion and the plan they have towards the retirements.

Based on the findings of this study, health workers were satisfied with the pay and promotion potentials of their workplaces. This finding was similar to the study conducted in Ogun state, Nigeria, where $38.2 \%$ of the workers liked their job because of the pay [21]. In contrast, the study conducted in Iran by [25] revealed that majority of healthcare workers were dissatisfied with their salaries. Pay and income plays a significant role in how health workers derive pleasure from their job, as relatively low pay can cause dissatisfaction and 
loss of motivation. The same applies to emigration towards higher-paying jobs. [18] also concluded a study and found that a healthy work environment for nurses in the primary health care settings is an important factor in improving work satisfaction, reducing turnover intention, and improving nursing care outcomes. A study concludes that workload, time pressures, and job control are to maintain morale among general practitioners [26].

\section{Conclusion and Recommendation}

Job satisfaction among healthcare professionals have significant effects on service delivery and healthcare professionals' lives. The results of the study have assessed that the job satisfaction in healthcare professionals in Ogun State Hospitals is highly associated with certain factors which need to be developed and focused on by the healthcare management. The study concludes that rewards or compensation (including attractive promotional schemes) have a great influence on the job satisfaction of healthcare professionals. In addition, other major factors that influence job satisfaction of healthcare workers in Ogun State Hospitals

\section{References}

[1] Tshamba, H.M., Yav, G.D., Didier, V., and Malonga, K.F., 2014, The assessment of job satisfaction for the healthcare providers in university clinics of Lubumbashi, Democratic Republic of Congo. Pan African Medical Journal, 19 (265), 1-12. doi:10.11604/pamj.2014.19.265.3138.

[2] Tzeng, H.M., 2002, The influence of nurses' working motivation and job satisfaction on intention to quit: An empirical investigation in Taiwan. International Journal of Nursing Studies, 39, 867878.

[3] Getnet, G., Yetnayet, S., Animut, A., and Yihalem, A.B., 2018, Level of Job Satisfaction and Associated factors among health care Professionals working at University of Gonder Referral Hospital, Northwest Ethiopia: A cross-sectional study. BMC include supervision, work environment, nature of work, and organizational management, respectively.

The management of public healthcare institutions of Ogun State needs to improve the Work Environment. In addition, healthcare professionals must be given attractive compensation, opportunities for career development, and promotions. This research was conducted on a small sample which limits its generalizability. Future researchers need to expand the scope of this study by focusing on a large sample so that its results can be generalized to the entire public health care sector of Nigeria.

\section{Conflicts of Interest}

There is no conflict of interest between the authors.

\section{Acknowledgements}

The author expresses his gratitude to all healthcare workers and the Department of Research Planning and Statistics (HMB) for their willingness and cooperation to participate in this study.

Res Notes, 11, 824. https://doi.org/10.1186/s13104018-3918-0.

[4] Raja, M.A., and Faraz, A.W., 2013, Factors influencing job satisfaction in public healthcare sector of Pakistan. Global Journal of Management and Business Research Administration and Management, 13(8), 60-66.

[5] Aziri, B., 2011, Job Satisfaction: A literature review. Management Research and Practice, 3, 7786.

[6] Ajayi K., 2004, Leadership, motivation, team work and information management for organizational efficiency. Niger J Soc Sci., 74(6), 1-16.

[7] International Council of Nurses-ICN, 2007, Positive practice environment: Quality workplaces quality patient care. Information and Action Tool Kit. Geneva: International Council of Nurses. Retrieved 
from: http://www.icn.ch/indkit2007pdf , accessed on 26/10/2020.

[8] Bjork, I.T., Samdal, G.B., Hansen, B.S., Torstad, S., and Hamilton, G.A., 2007, Job satisfaction in a Norwegian population of nurses: a questionnaire survey. International Journal of Nursing Studies, 44 (5), $747-757$.

[9] El - Jardali, F., Dimassi, H., Dmit, N., Jamal, D., and Muo, G., 2009, A national cross-sectional study on nurses' intent to leave and job satisfaction in Lebanon: Implications for policy and practice. $B M C$ Nursing, 8 (3), 1-13. https://doi.org/10.1186/14726955-8-3.

[10] Park, J.S., and Kim, T.H., 2009, Do types of organizational culture matter in nurses' job satisfaction and turnover intention. Leadership in Health Services, 22 (1), 20 - 38.

[11] Asegid, A., Belachew, T., and Yimam, E., 2014, Factors influencing job satisfaction and anticipated turnover among nurses in Sidama Zone public health facilities, South Ethiopia. Nursing Research and Practice, 2014 (Article ID 909768), 1-26. Doi:10.1155/2014/909768.

[12] Chang, E., Cohen, J., Koethe, B., Smith, K., and Bir, A., 2017, Measuring job satisfaction among healthcare staff in the United States: A confirmatory factor analysis of the Satisfaction of Employees in Health Care (SEHC) survey. International Journal for Quality in Health care, 29 (2), 262-268. DOI: 10.1093/intqhc/mzx012.

[13] Ayele, G., Negga, B., Gudina, E.A., and Yadeta, D., 2015, Job satisfaction and associated factors among health care providers at public health institutions in Harari region, eastern Ethiopia: a cross-sectional study. BMC Res Notes, 8, 1-7. DOI 10.1186/s13104-015-1368-5.

[14]Ali Khan Khuwaja 1, Riaz Qureshi, Marie Andrades, Zafar, F., Khan, N.K., 2004, Comparison of job satisfaction and stress among male and female doctors in teaching hospitals of Karachi. J Ayub Med Coll Abbottabad, 16,23-7.

[15] National Population Commission, 2006, Federal Republic of Nigeria 2006 Population and Housing Census, Priority Tables, Vol. VII Abuja, Nigeria.

[16]Department of Planning Research and Statistics (DPRS), 2019, Ogun State Hospitals Management
Board, Ogun State, Nigeria. https://www.ogunstate.gov.ng/ohmb/.

[17] Yakasai, I.A., Ugwa, E.A., and Abubakar, I.S., 2013, Job Satisfaction among Resident Doctors in a Tertiary Healthcare Facility in Northern Nigeria; A Cross-Sectional Survey. Trop J Obstet Gynecol. 2013; 30 (1), 89 - 96.

[18] Ayamolowo, S.J., Irinloye, O., and Oladoyin, M.O., 2013, Job Satisfaction and Work Environment of Primary Health Care Nurses in Ekiti State, Nigeria: An Exploratory Study. International Journal of Caring Sciences, 6 (3), 531-542.

[19]Ezeja, E.B., Azodo, C.C., Ehizele, A.O., Ehigiator, O., and Oboro, H.O., 2010, Assessment of job satisfaction and working conditions of Nigerian oral health workers. International Journal of Biomedical and Health Sciences, 6(3).143-150. Retrieved from http://www.klobex.org/journals/ijbhs/ijbhs6/ijbhs63 0610054.pdf. Accessed on 20/09/20.

[20] Olusegun, E.A., and Olusoji, J.G., 2020, Work environment and job satisfaction among nurses in government tertiary hospitals in Nigeria. Rajagiri Management Journal, 14(1), 71-92. https://doi.org/10.1108/RAMJ-01-2020-0002.

[21]Ebuehi, O.M., and Campbell, P.C., 2011, Attraction and retention of qualified health workers to rural areas in Nigeria: A case study of four Local Government Areas in Ogun State, Nigeria. Rural and Remote Health, 11, 1515. (online), www.rrh.org.au [22] Jathanna, R., Melisha, R.D., Mary, G., and Latha, K.S., 2011, Determinants of job satisfaction among health care workers at a tertiary care hospital. Online Journal of Health and Allied Sciences, 10 (3). 5 .

[23] Peters, D.H., Chakraborty, S., Mahapatra, P., and Steinhardt, L., 2010, Job satisfaction and motivation of health workers in public and private sectors: Cross-sectional analysis from two Indian states. Hum Resour Health, 8, 27. DOI: 10.1186/1478-4491-8-27. [24] Malliarou, M., Sarafis, P., Moustaka, E., Kouvela, T., and Constantinidis, T.C., 2010, Greek registered nurses' job satisfaction in relation to workrelated stress. A Study on Army and Civilian Rns. Global Journal of Health Science, 2, 1. DOI: 10.5539/gjhs.v2n1p44. 
[25] Kebriaei, A., and Moteghedi, M.S., 2009, Job satisfaction among community health workers in Zahedan District, Islamic Republic of Iran. East Mediterr Health J., 15(5), 1156-63.
[26]Diane, W., Chris, B., Hugh, G., and Bonnie, S., 2006, GP job satisfaction in view of contract reform: A national survey. Br J Gen Pract., 56(523), 87-92. 